\title{
Two distinct roles of Atlantic SSTs in ENSO variability: North Tropical Atlantic SST and Atlantic Niño
}

\author{
Yoo-Geun Ham, ${ }^{1,2}$ Jong-Seong Kug, ${ }^{3}$ and Jong-Yeon Park ${ }^{4}$ \\ Received 30 May 2013; revised 5 July 2013; accepted 8 July 2013; published 1 August 2013.
}

[1] Two distinct roles of the Atlantic sea surface temperatures (SSTs), namely, the North Tropical Atlantic (NTA) SST and the Atlantic Niño, on the El Niño-Southern Oscillation (ENSO) variability are investigated using the observational data from 1980 to 2010 and coupled model experiments. It appears that the NTA SST and the Atlantic Niño can be used as two independent predictors for predicting the development of ENSO events in the following season. Furthermore, they are likely to be linked to different types of El Niño events. Specifically, the NTA SST cooling during February, March, and April contributes to the central Pacific warming at the subsequent winter season, while the negative Atlantic Niño event during June, July, and August contributes to enhancing the eastern Pacific warming. The coupled model experiments support these results. With the aid of a lagged inverse relationship, the statistical forecast using two Atlantic indices can successfully predict various ENSO indices. Citation: Ham, Y.-G., J.-S. Kug, and J.-Y. Park (2013), Two distinct roles of Atlantic SSTs in ENSO variability: North Tropical Atlantic SST and Atlantic Niño, Geophys. Res. Lett., 40, 4012-4017, doi:10.1002/grl.50729.

\section{Introduction}

[2] Recently, there has been increasing evidence for the role of Atlantic sea surface temperature (SST) on the El NiñoSouthern Oscillation (ENSO) variability [Dommenget et al., 2006; Dong et al., 2006; Jansen et al., 2009; RodriguezFonseca et al., 2009; Ding et al., 2012; Ham et al., 2013]. After the recognition of the equatorial Atlantic SST variability, often called the Atlantic Niño [Merle et al., 1980; Servain et al., 1982; Keenlyside and Latif, 2007], its possible role on ENSO has been examined by several pioneer works. According to these studies, the Atlantic Niño during the boreal summer can lead to La Niña during the subsequent winter season through the strengthening of the Walker circulation with an ascending branch over the Atlantic and a descending branch over the western Pacific. Then, the low-level easterly in the western Pacific triggers coupled processes to develop a La Niña [Rodriguez-Fonseca et al., 2009].

[3] Meanwhile, Ham et al. [2013] discovered the unique role of the North Tropical Atlantic (NTA) SST during the

\footnotetext{
${ }^{1}$ Global Modeling and Assimilation Office, NASA Goddard Space Flight Center, Greenbelt, Maryland, USA.

${ }^{2}$ Goddard Earth Science Technology \& Research, Morgan State University, Baltimore, Maryland, USA.

${ }^{3}$ Korea Institute of Ocean Science and Technology, Ansan, South Korea.

${ }^{4}$ Max Planck Institute for Meteorology, Hamburg, Germany.

Corresponding author: J.-S. Kug, Korea Institute of Ocean Science and Technology, Ansan, South Korea. (jskug@kiost.ac)

(C2013. American Geophysical Union. All Rights Reserved. 0094-8276/13/10.1002/grl.50729
}

boreal spring on ENSO during the subsequent winter season. They found that the NTA SST can trigger the warm pool (WP) type of El Niño through the subtropical teleconnection along the Pacific Intertropical Convergence Zone (ITCZ). They identified a subtropical teleconnection along the offequatorial Pacific ITCZ, which relays the Atlantic signal to the west: The spring warming in the NTA SST can induce a low-level anticyclonic flow over the western Pacific from the boreal summer, then this flow generates easterly winds over the western equatorial Pacific to cool the equatorial Pacific SST and to trigger a La Niña during the following winter.

[4] Though previous studies emphasized the role of the Atlantic Niño and NTA SST on ENSO variability, it is not yet clear whether these two SSTs are independent or not, and whether they have distinct roles on ENSO. This paper is intended to show the distinct roles of the NTA SST and Atlantic Niño on ENSO variability. In section 2, descriptions of the observational data and coupled (ocean-atmosphere) general circulation model (CGCM) used in this study are provided. The distinct roles of the NTA SST and Atlantic Niño are shown in section 3. Summary and conclusions are presented in section 4 .

\section{Observational Data and CGCM for Partially Coupled Experiments}

[5] The monthly mean $850 \mathrm{hPa}$ wind and precipitation from 1980 to 2010 are obtained from the Modern-Era Retrospective Analysis for Research and Applications [Rienecker et al., 2011]. The observed SST data during 1980-2010 are the improved Extended Reconstructed Sea Surface Temperature version 2 [Smith and Reynolds, 2004]. All the data used in this study are detrended first.

[6] For partially coupled experiments, the GFDL CM2.1, which is developed by the Geophysical Fluid Dynamics Laboratory, is utilized [Delworth et al., 2006]. In order to consider the impact of the Atlantic SST, a set of three ensemble simulations are conducted. In each ensemble run, the CGCM is integrated with the observed SST only over the Atlantic Ocean $\left(35^{\circ} \mathrm{S}-65^{\circ} \mathrm{N}\right)$ from 1951 to 2010 , and the last 30 year integration is used for analysis. Note that full air-sea coupling is applied everywhere except in the Atlantic, where model SSTs are nudged to the observations with a time scale of 5 days.

\section{Roles of NTA SST and Atlantic Niño in the Pacific SST Variability}

[7] To compare the role of the NTA SST and that of the Atlantic Niño, Figure 1 shows lagged regressions using the NTA SST index $\left(80^{\circ} \mathrm{W}-20^{\circ} \mathrm{E}, 0^{\circ} \mathrm{N}-15^{\circ} \mathrm{N}\right)$ during February, March, and April (FMA) and the Atlantic Niño 


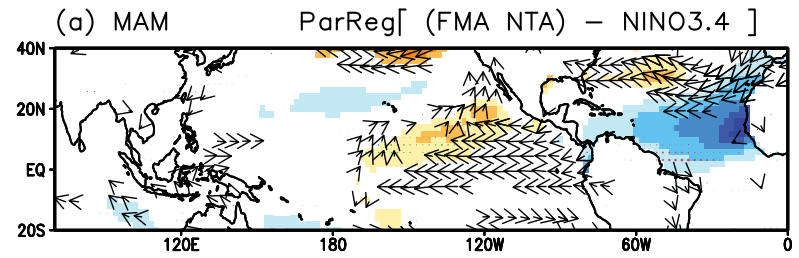

(c) JJA

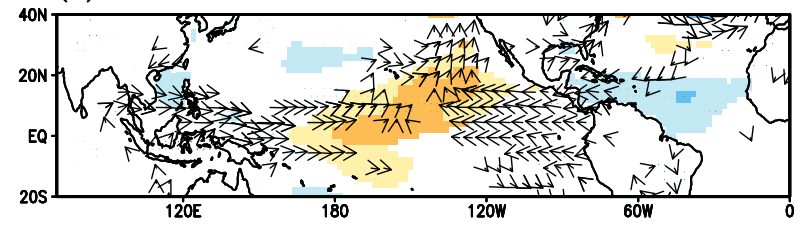

(e) SON

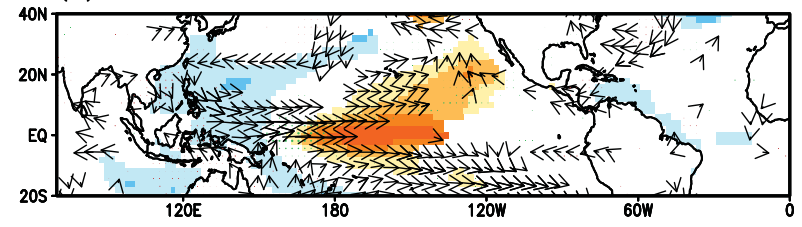

(g) DJF

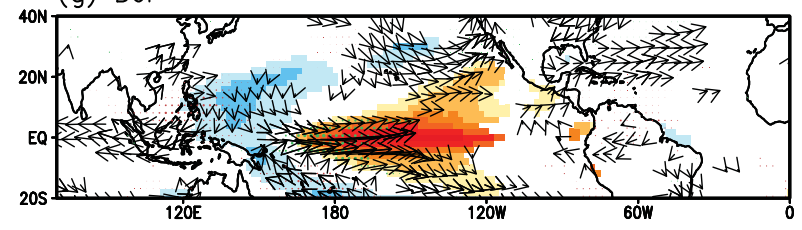

(b) MAM ParReg[ (JJA AtI3) - NINO3.4 ]

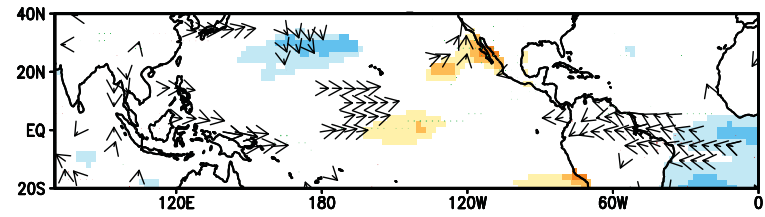

(d) JJA

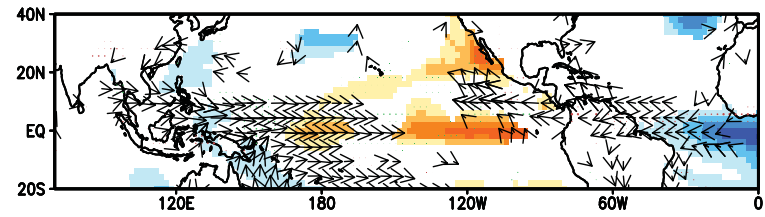

(f) SON

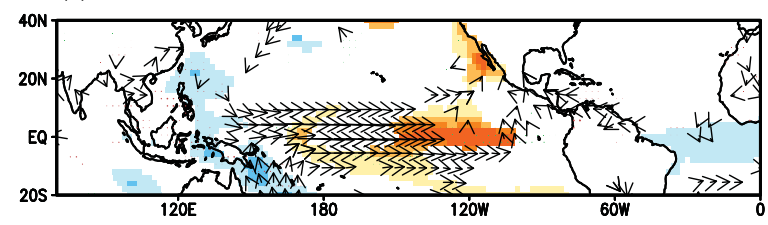

(h) DJF

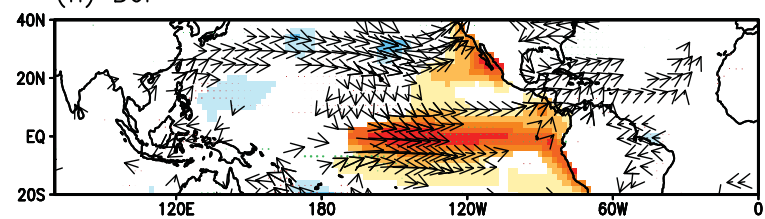

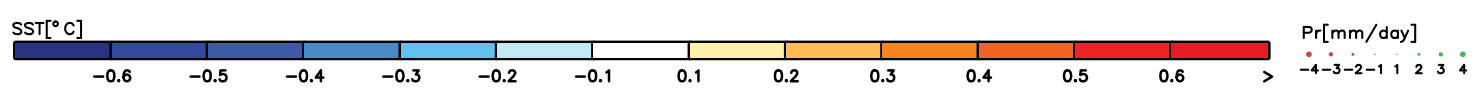

Figure 1. Lagged regressions of 3 month averaged SST $\left({ }^{\circ} \mathrm{C}\right)$, wind vector at $850 \mathrm{hPa}(\mathrm{m} / \mathrm{s})$, and precipitation (mm/d) during (a) MAM, (c) JJA, and (e) SON, and (d) DJF onto NTA SST $\left(90^{\circ} \mathrm{W}-20^{\circ} \mathrm{E}, 0^{\circ} \mathrm{N}-15^{\circ} \mathrm{N}\right)$ averaged during FMA, after excluding the impact of NINO3.4 SST $\left(170^{\circ} \mathrm{W}-120^{\circ} \mathrm{W}, 5^{\circ} \mathrm{S}-5^{\circ} \mathrm{N}\right)$ during the previous DJF from 1980 to 2010 . The right panels are the same as the left panels, except for the Atlantic Niño index (i.e., the Atl3 index over $20^{\circ} \mathrm{W}-0^{\circ} \mathrm{W}, 3^{\circ} \mathrm{S}-3^{\circ} \mathrm{N}$ ) during JJA. Only the values at the $95 \%$ confidence level or higher are shown. Figures 1a, 1c, and 1e are slightly modified from Ham et al. [2013, Figure 1].

index (i.e., the Atl3 index for $20^{\circ} \mathrm{W}-0^{\circ} \mathrm{W}, 3^{\circ} \mathrm{S}-3^{\circ} \mathrm{N}$ ) during June, July, and August (JJA). Since the ENSO can be induced internally within the Pacific due to its oscillatory nature, we apply partial regression to linearly remove the impact of NINO3.4 SST $\left(170^{\circ} \mathrm{W}-120^{\circ} \mathrm{W}, 5^{\circ} \mathrm{S}-5^{\circ} \mathrm{N}\right)$ during previous December, January, and February (DJF) as in Ham et al. [2013]. In spite of the presence of the nonlinear complexity of ENSO, the partial regression is an alternative way to isolate the impact of the Atlantic SST from the oscillating nature of ENSO. Note that the regressions denote the changes with respect to the one standard deviation change of the indices, and we multiply the regression by minus one to focus on the El Niño events.

[8] The NTA cooling during FMA induces suppressed convection over the equatorial Atlantic during March, April, and May (MAM) (Figure 1a), and it generates low-level anticyclonic flow over the eastern Pacific as a Gill-type Rossby wave response [Gill, 1980]. On the western flank of this anticyclonic flow, reduced wind speed and warm wet moist energy advection due to the southerly leads to SST warming with enhanced convective activity [Xie, 1999; Ham et al., 2007]. During JJA, this positive precipitation and SST warming over the off-equatorial central Pacific provide low-level cyclonic flow over the central western Pacific, which leads to equatorial westerly over the western Pacific (Figure 1c). At the same time, there is equatorial easterly over the eastern Pacific, so the wind response to the NTA SST is opposite over the western and eastern Pacific. It means that the thermocline deepening due to the equatorial westerly over the western Pacific is compensated by the thermocline shoaling due to the local easterly over the eastern Pacific. Therefore, the SST change over the eastern Pacific is relatively weak, preferring central Pacific warming [Kug et al., 2009, 2010]. It implies that the opposite wind response is a key to trigger the WP El Niño response to the NTA SST (Figures $1 \mathrm{e}$ and $1 \mathrm{~g}$ ).

[9] On the other hand, the Atlantic Niña is likely to enhance SST warming over the eastern Pacific, namely, the El Niño modulated by the Atlantic Niña tends to be a canonical one. This is because the easterly over the equatorial far-eastern Pacific is considerably weaker with the Atlantic Niña. During JJA, the equatorial easterly driven by the Atlantic Niña is nearly zero over the equatorial eastern Pacific, while significant easterly is induced by the NTA SST over $140^{\circ} \mathrm{W}-90^{\circ} \mathrm{W}$ (Figures 1c and 1d).

[10] The other difference is that the wind anomaly is mainly over the equator in the case of the Atlantic Niña 


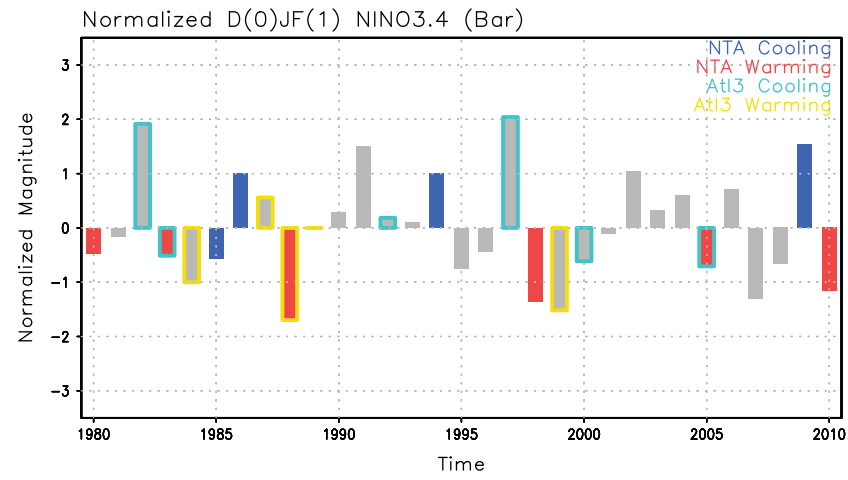

Figure 2. Time series of DJF NINO3.4 SST from 1980 to 2010. The years with NTA warming (NTA SST greater than one standard deviation) and cooling (NTA SST smaller than negative one standard deviation) during the previous FMA are denoted by red and blue bars, respectively, and positive and negative Atlantic Niños are outlined by yellow and light blue, respectively.

during the El Niño developing phase, while the NTA SST affects the subtropical North Pacific variability. That is, the Atlantic Niña modulates the ENSO through altering the Walker circulation [Rodriguez-Fonseca et al., 2009], implying that its primary mechanism is substantially different from that for the NTA SST, which affects the Pacific variability along the Pacific ITCZ [Ham et al., 2013]. It is also consistent with Boschat et al. [2013] that the North Pacific variability during boreal spring season can enhance ENSO predictability during subsequent winter season.

[11] As shown in Figure 1, the NTA SST and Atlantic Niño are linked to different spatial patterns of SSTs over the tropical Pacific in the following seasons, implying that they favor development of the different types of El Nino during subsequent boreal winter season. To check individual ENSO events associated with the two types of Atlantic variability, Figure 2 shows the time series of $\mathrm{D}(0) \mathrm{JF}(1)$ NINO3.4 SST from 1980 to 2010 with significant FMA(0) NTA SST or JJA(0) Atlantic Niño. To have a glance at the relationship between Atlantic SSTs and the ENSO, years with NTA warming (NTA SST greater than one standard deviation) and cooling (smaller than minus one standard deviation) are denoted by red and blue bars, respectively, and positive and negative Atlantic Niño are outlined by yellow and light blue, respectively. There are six cases of NTA warming, and in every case, a negative NINO3.4 SST follows. Similarly, three of the four cases of NTA cooling show positive NINO3.4 SST during the following DJF. This implies that the NTA SST during the boreal spring has a strong inverse relationship with the ENSO during the following winter season. Interestingly, the three El Niño cases after NTA cooling were in 1986/1987, 1994/1995, and 2009/2010, whose SST anomalies were mostly located over the central Pacific, indicating that the NTA cooling played a role in enhancing central Pacific warming. In the case of the Atlantic Niño, there are five positive cases, and three of them are followed by Pacific SST cooling. In addition, among six negative Atlantic Niño cases, three of them are linked to the Pacific SST warming, confirming the negative relationship between the Atlantic Niño and the ENSO. Interestingly, some negative Atlantic Niño events coincide with the strongest El Niño cases (i.e., 1982/1983 and 1997/1998) in the twentieth century [Keenlyside et al., 2013]. This implies that the Atlantic Niño may help to develop the strongest El Nino events. Note that the differences in the La Niña led by the two types of Atlantic SSTs are not clear as those in the El Niño, as Kug and Ham [2011] pointed out that the La Niña events are hard to distinguish based on their spatial patterns.

[12] This analysis also confirms that the two Atlantic SSTs are independent predictors of the ENSO. That is because there were only two significant NTA SST events among a total of 10 cases that were overlapped with significant Atlantic Niño events (i.e., 1983/1984 and 1988/1989). The correlation coefficient between FMA NTA and JJA Atl3 indices is less than 0.1 during 1980-2010. In addition, the lead-lag correlation coefficients between FMA NTA SST and 3 month moving average Atlantic Niño index do not show any significant relation at the $95 \%$ significant level (less than 0.3 for the correlation, not shown), implying that they are independent precursors for ENSO development.

[13] With the aid of a solid negative relationship between Atlantic SSTs that contribute to ENSO with several months of time lag, Atlantic SSTs can be powerful and reliable predictors for ENSO. To investigate how much the ENSO forecast skill is contributed with Atlantic SSTs, statistical prediction with the NTA SST and Atlantic Niño is performed using a simple linear regression method. We use the FMA(0) NTA SST or JJA(0) Atlantic Niño from 1980 to 2010 to predict D (0)JF(1) NINO4, NINO3.4, and NINO3. The time series (a) $\mathrm{NINO} 4$

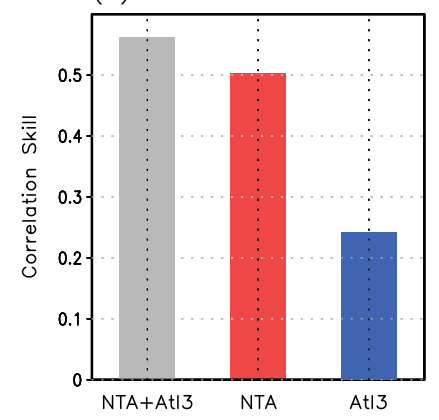

(b) NINO3.4

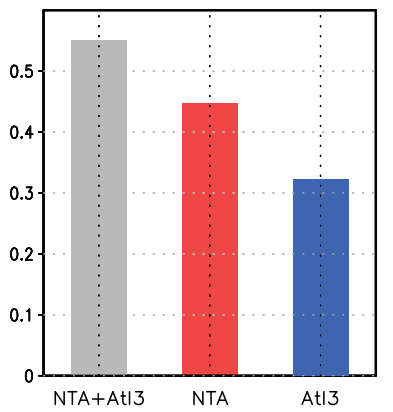

(c) $\mathrm{NINO3}$

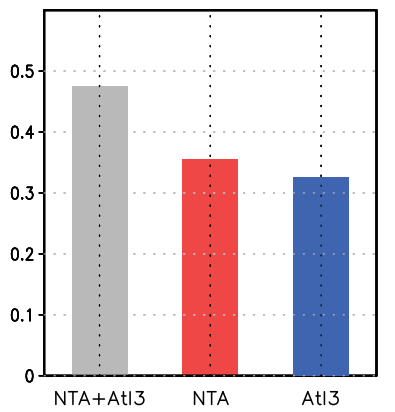

Figure 3. The correlation skill with the observed and statistically predicted DJF (a) NINO4, (b) NINO3.4, and (c) NINO3 indices from 1980 to 2010 using the linear regression method. The gray bar denotes the correlation skill of the statistical forecast with two predictands of the NTA SST and Atlantic Niño indices. The red and blue bars denote the correlation skills with the NTA SST and Atlantic Niño indices, respectively. 

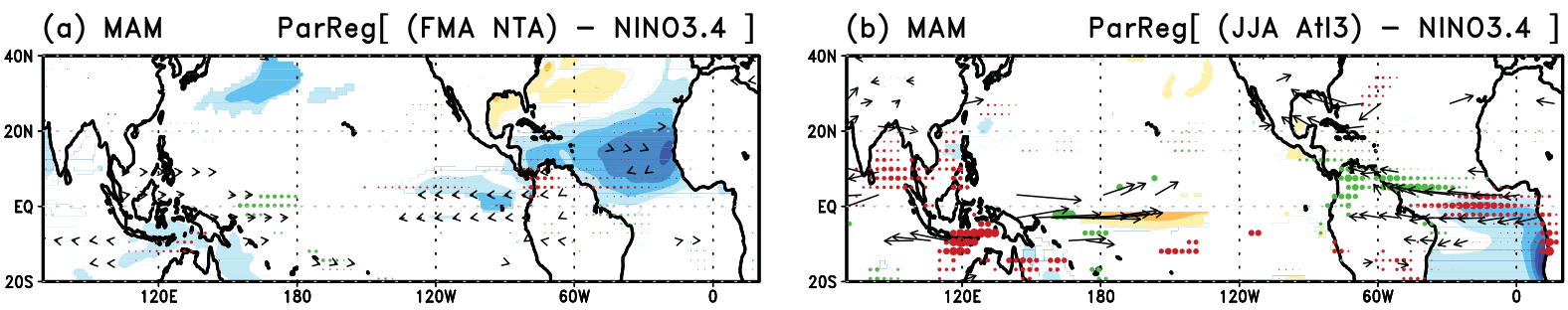

(c) JJA

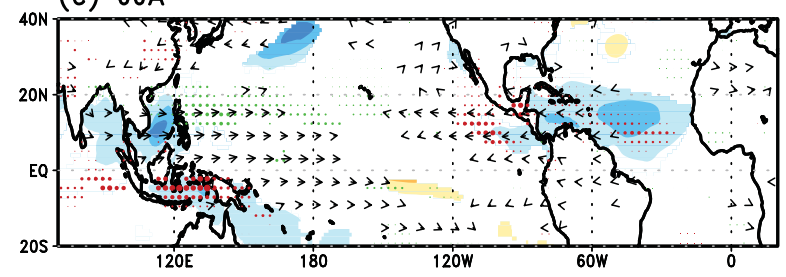

(d) JJA

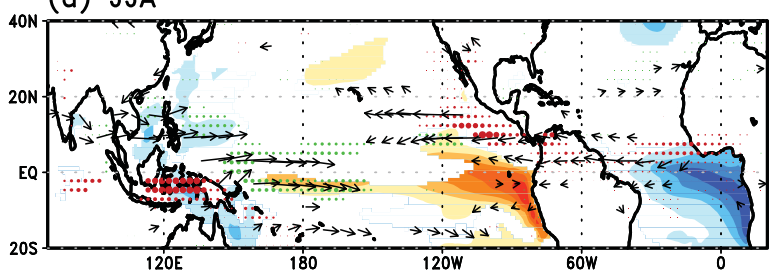

(e) SON
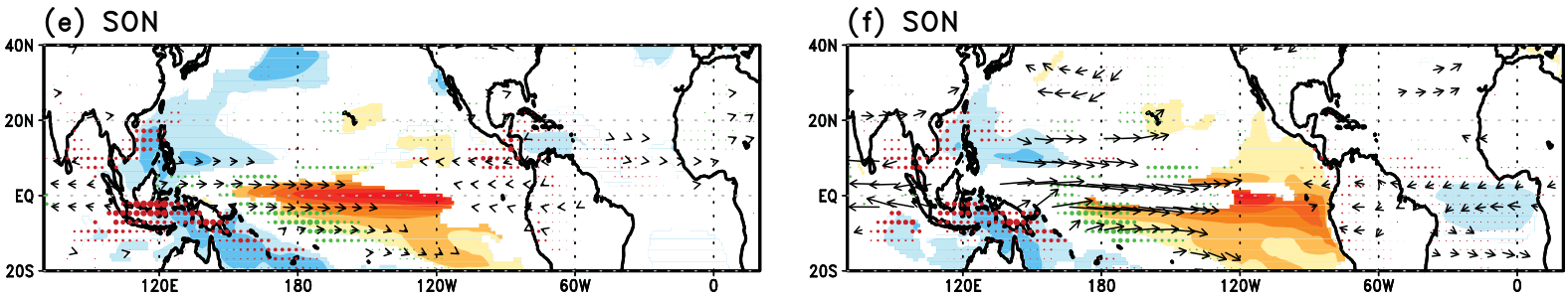

(g) DJF

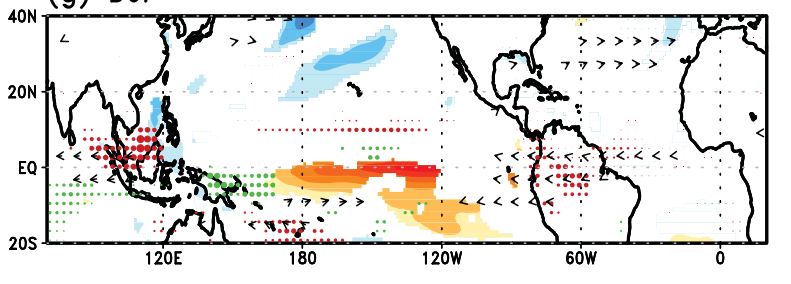

SST $\left[{ }^{\circ} \mathrm{C}\right]$

(h) DJF

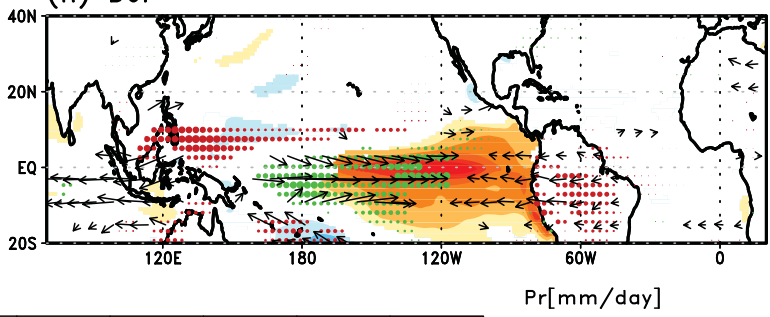

$\operatorname{Pr}[\mathrm{mm} / \mathrm{day}]$

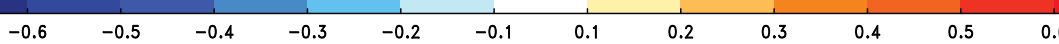

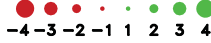

Figure 4. Lagged regressions using partially coupled CGCM experiments from 1980 to 2010. The regression of 3 month averaged SST, wind vector at $850 \mathrm{hPa}$ (vector), and precipitation during (a) MAM, (c) JJA, (e) SON, and (g) DJF onto the FMA NTA SST. The right panels are same as the left panels, except for the JJA Atlantic Niño index (i.e., the Atl3 index over $\left.20^{\circ} \mathrm{W}-0^{\circ} \mathrm{W}, 3^{\circ} \mathrm{S}-3^{\circ} \mathrm{N}\right)$.

contains all ENSO signals, and it is shown that the skill of the statistical prediction is insensitive whether the preceding D $(-1) \mathrm{JF}(0)$ ENSO signal is contained or not, even though the skill of the NINO3 index is slightly decreased with ENSO-removed time series (i.e., about 0.05). Note that multiple linear regression is applied when two predictors are used together, and the popular leave-one-out cross-validation method is applied by excluding the observed value at the target year.

[14] Figure 3 shows the correlation skill between the observed and statistically predicted NINO indices. With the two Atlantic predictors (i.e., NTA SST and Atlantic Niño), the correlation skill over the NINO4 region is 0.56 , which implies that the Atlantic SSTs can be a useful tool to predict ENSO in advance. With a single predictor, the correlation skills associated with the NTA SST and Atlantic Niño are 0.50 and 0.24 , respectively, showing that the NTA SST is a more reliable predictor of central Pacific SST variability. It also shows that the sum of explained variance using NTAonly $(25.0 \%)$ and Atl3-only (5.7\%) predictions is quite similar to that using both indices $(31.3 \%)$, consistent with the previous notions that they are independent predictors.

[15] The correlation skill of the NINO3.4 index shows a similar behavior; however, the skill with the NTA SST is slightly decreased, and that with the Atlantic Niño index increased. Over the NINO3 region, the correlation skill with the two predictors is relatively lower than that of NINO4 or NINO3.4, and it is because the predictability with the NTA SST becomes lower over the eastern Pacific. The correlation skill with the NTA SST drops to 0.35 , even though it is still higher than that with the Atlantic Niño (i.e., 0.32).

[16] In summary, we wish to note the following. First, the NTA SST gives a higher correlation skill over the central Pacific SST. Second, the Atlantic Niño is likely related to the SST variability over the eastern Pacific. Finally, the correlation skill is systematically higher with two predictors than with any single predictor, implying that the two predictors are independent.

[17] So far, the distinct roles of NTA SSTs and Atlantic Niño have been examined using the observational data. 
However, such analysis has a limitation due to small samplings. Next, this observed relationship is tested by partially coupled experiments using CGCM similar to those of Ding et al. [2012]. Figure 4 shows the partial lagged regression of SST, precipitation, and $850 \mathrm{hPa}$ wind onto $\mathrm{FMA}(0) \mathrm{NTA}$ SST and JJA(0) Atlantic SST as in Figure 1. During JJA, the equatorial easterly led by the NTA SST is clear over the fareastern Pacific as observed. At the same time, there is equatorial westerly over the western Pacific along with cyclonic flow over the subtropical western Pacific. As a result, a WP type of El Niño develops up to September-October-November (SON), and then, it is weakened during DJF season. This means that the model experiments successfully mimic the notable variability over the Pacific led by the NTA SST, even though there is some systematic errors in seasonal evolution.

[18] For the Atlantic Niño-related forcing, the SST warming over the eastern Pacific is induced in JJA due to the equatorial westerly over the western Pacific. Being different from the response to the NTA SST, there is no significant wind anomaly over the eastern Pacific; therefore, the SST anomalies are mainly located over the eastern Pacific. This partially coupled experiment confirms that the Atlantic SSTs can trigger the canonical ENSO variability. Especially, it is shown that there are systematic differences between the El Niño led by the NTA SST and that by the Atlantic Niño, implying that the two types of Atlantic SSTs can be unique precursors of the two types of El Niño events.

\section{Summary and Conclusion}

[19] In this study, the roles of NTA SST and Atlantic Niño are compared. The lagged regression and time series analysis show that the two types of Atlantic SSTs are independent indicators of ENSO variability, contributing to different types of El Niño events. Specifically, the NTA SST cooling during FMA is linked to the WP type (i.e. 1994/1995 and 2009/ 2010) or the mixed type (i.e., SST center is between that in WP and canonical El Niño, 1986/1987 case) of El Niño at the subsequent winter season. In contrast, a negative Atlantic Niño event during JJA is followed by the canonical El Niño (i.e., 1982/83 and 1997/98). The partially coupled experiments successfully mimic the main characteristics of El Niño events led by the NTA SST and Atlantic Niño.

[20] With the aid of a clear inverse relationship with several months of time lag, the statistical forecast using two Atlantic indices successfully predict various ENSO indices to some extent. The forecast skill for the NINO4 (NINO3) index is $0.56(0.47)$. Between two SSTs, the NTA SST has a stronger connection with the Pacific SST variability, that is, the statistical forecast results show that FMA NTA SST systematically has a greater impact on forecast skill than the JJA Atlantic Niño index even with a longer lead time.

[21] As this study suggests that the two Atlantic precursors can explain the variability of two types of El Niño events in advance, the ENSO prediction of dynamical models can be improved if they reflect the Atlantic influences reasonably. In particular, the NTA SST can be critical for the prediction of WP El Niño. Previous studies reported that the forecast skill for the WP El Niño is considerably lower than that for the canonical El Niño [Hendon et al., 2009; Jeong et al., 2012]. Therefore, it is worthwhile to examine how well the climate models simulate these Atlantic SSTs and their influences on ENSO.
[22] Though the present study focuses on the roles of Atlantic SSTs, there are other studies that focus on the roles of Indian Ocean SST in ENSO [Kug and Kang, 2006; Kug et al., 2005, 2006; Ohba and Ueda, 2007; Izumo et al., 2010; Luo et al., 2010]. They pointed out that there are significant differences in ENSO evolution with and without the Indian Ocean warming or the Indian Ocean Dipole. In addition, the linkage between Atlantic SST and Indian monsoon or SST variability was reported [Kucharski et al., 2008, 2009; Wang et al., 2006]. This means that the interbasin interactions are crucial to improve our understanding of the global SST variability as well as of the ENSO. Therefore, it is important to shed new light on understanding the interactions among difference basins of the Indian, Atlantic, and Pacific Oceans.

[23] Acknowledgments. This work was funded by the Korea Meteorological Administration Research and Development Program under grant CATER 2012-3042 and KIOST (PE99162). The modeling integration was supported by grant KSC-2012-C2-25 from Korea Institute of Science and Technology Information.

[24] The Editor thanks two anonymous reviewers for their assistance in evaluating this paper.

\section{References}

Boschat, G., P. Terray, and S. Masson (2013), Extratropical forcing of ENSO, Geophys. Res. Lett., 40, 1-7, doi:10.1002/grl.50229.

Delworth, T. L., et al. (2006), GFDL's CM2 global coupled climate models. Part I: Formulation and simulation characteristics, J. Clim., 19, 634-674.

Ding, H., N. S. Keenlyside, and M. Latif (2012), Impact of the equatorial Atlantic on the El Niño Southern Oscillation, Clim. Dyn., 38, 1965-1972, doi:10.1007/s00382-011-1097-y.

Dommenget, D., V. Semenov, and M. Latif (2006), Impacts of the tropical Indian and Atlantic Oceans on ENSO, Geophys. Res. Lett., 33, L11701, doi:10.1029/2006GL025871.

Dong, B.-W., R. T. Sutton, and A. A. Scaife (2006), Multidecadal modulation of El Nino-Southern Oscillation (ENSO) variance by Atlantic Ocean Sea Surface Temperatures, Geophy. Res. Lett., 33, L08705, doi:10.1029/2006GL025766.

Ham, Y.-G., J.-S. Kug, and I.-S. Kang (2007) Role of moist energy advection in formulating anomalous Walker Circulation associated with ENSO, J. Geophys. Res., 112, D24105, doi:10.1029/2007JD008744.

Ham, Y.-G., J.-S. Kug, J.-Y. Park, and F.-F. Jin (2013), Sea surface temperature in the north tropical Atlantic as a trigger for El Niño/Southern Oscillation events, Nat. Geosci., 6, 112-116, doi:10.1038/ngeo1686.

Hendon, H. H., E. Lim, G. Wang, O. Alves, and D. Hudson (2009), Prospects for predicting two flavors of El Nino, Geophys. Res. Lett., 36, L19713, doi:10.1029/2009GL040100.

Gill, A. E. (1980), Some simple solutions for the heat induced tropical circulation, Q. J. R. Meteorol. Soc., 106, 447-462.

Izumo, T., J. Vialard, M. Lengaigne, C. de Boyer Montegut, S. K. Behera, J.-J. Luo, S. Cravatte, S. Masson, and T. Yamagata (2010), Influence of the state of the Indian Ocean Dipole on following year's El Niño, Nat. Geosci., 3, 168-172.

Jansen, M. F., D. Dommenget, and N. Keenlyside (2009), Tropical atmosphereocean interactions in a conceptual framework, J. Clim., 22, 550-567.

Jeong, H.-I., D. Y. Lee, K. Ashok, J.-B. Ahn, J.-Y. Lee, J.-J. Luo, J.-K. E. Schemm, H. H. Hendon, K. Braganza, and Y.-G. Ham (2012), Assessment of the APCC coupled MME suite in predicting the distinctive climate impacts of two flavors of ENSO during boreal winter, Clim. Dyn., 39, 475-493, doi:10.1007/s00382-012-1359-3.

Keenlyside, N. S., and M. Latif (2007), Understanding equatorial Atlantic interannual variability, J. Clim., 20, 131-142.

Keenlyside, N. S., H. Ding, and M. Latif (2013), Potential of equatorial Atlantic variability to enhance El Niño prediction, Geophys. Res. Lett., 40, 2278-2283, doi:10.1002/grl.50362.

Kucharski F., A. Bracco, J. H. Yoo, and F. Molteni (2008), Atlantic forced component of the Indian monsoon interannual variability, Geophys. Res. Lett., 33, L04706, doi:10.1029/2007GL033037.

Kucharski, F., A. Bracco, J. H. Yoo, A. Tompkins, L. Feudale, P. Ruti, and A. dell'Aquila (2009), A Gill-Matsuno-type mechanism explains the tropical Atlantic influence on African and Indian monsoon rainfall, $Q . J$. R. Meteorol. Soc., 135, 569-579.

Kug, J.-S., and I.-S. Kang (2006), Interactive feedback between the Indian Ocean and ENSO, J. Clim., 19, 1784-1801. 
HAM ET AL.: ROLE OF ATLANTIC SSTS ON ENSO

Kug, J.-S., S.-I. An, F.-F. Jin, and I.-S. Kang (2005), Preconditions for El Niño and La Niña onsets and their relation to the Indian Ocean, Geophys. Res. Lett., 32, L05706, doi:10.1029/2004GL021674.

Kug, J.-S., B. P. Kirtman, and I.-S. Kang (2006), Interactive feedback between ENSO and the Indian Ocean in an interactive coupled model, J. Clim., 19, 6371-6381.

Kug, J.-S., J. Choi, S.-I. An, F.-F. Jin, and A. T. Wittenberg (2010), Warm pool and cold tongue El Nino events as simulated by the GFDL 2.1 coupled GCM, J. Clim., 23, 1226-1239.

Kug, J.-S., F.-F. Jin, and S.-I. An (2009), Two-types of El Nino events: Cold tongue El Nino and warm Pool El Nino, J. Clim., 22, 1499-1515.

Kug, J.-S., and Y.-G. Ham (2011), Are there two types of La Niña?, Geophy. Res. Lett., 38, L16704, doi:10.1029/2011GL048237.

Luo, J.-J., R. Zhang, S. K. Behera, Y. Masumoto, F.-F. Jin, R. Lukas, and T. Yamagata (2010), Interaction between El Niño and extreme Indian Ocean dipole, J. Clim., 23, 726-742.

Merle, J., M. Fieux, and P. Hisard (1980), Annual signal and interannual anomalies of sea surface temperature in the eastern equatorial Atlantic Ocean, Deep Sea Res., 26, 77-101.
Ohba, M., and H. Ueda (2007), An impact of SST anomalies in the Indian Ocean in acceleration of the El Niño to La Niña transition, J. Meteorol. Soc. Jpn., 85, 335-348.

Rienecker, M. M., et al. (2011), MERRA-NASA's modern-era retrospective analysis for research and applications, J. Clim., 24, 3624-3648, doi:10.1175/JCLI-D-11-00015.1.

Rodriguez-Fonseca, B., I. Polo, J. García-Serrano, T. Losada, E. Mohino, C. R. Mechoso, and F. Kucharski (2009) Are Atlantic Niños enhancing Pacific ENSO events in recent decades?, Geophys. Res. Lett., 36, L20705, doi:10.1029/2009GL040048.

Servain, J., J. Picaut, and J. Merle (1982), Evidence of remote forcing in the equatorial Atlantic Ocean, J. Phys. Oceanogr., 12, 457-463.

Smith, T., and R. Reynolds (2004), Improved extended reconstruction of SST (1854-1997), J. Clim., 17, 2466-2477.

Wang, C., D. B. Enfield, S. - K. Lee, and C. W. Landsea (2006), Influences of the Atlantic warm pool on Western Hemisphere summer rainfall and Atlantic hurricanes, J. Clim., 19, 3011-3028.

Xie, S. P. (1999), A dynamic ocean-atmosphere model of the tropical Atlantic decadal variability, J. Clim., 12, 64-70. 